\title{
The Effect of Coach Leadership, Team Cooperation, and Achievement Motivation on The Performance of The Depok City Athlete
}

\author{
Muhammad Fahmi \\ State University of Jakarta \\ Email: muhammafahmi_im13s3@mahasiswa.unj.ac.id \\ Wibowo \\ State University of Jakarta \\ Email:wibowo303@yahoo.co.id \\ Dedi Purwana \\ State University of Jakarta \\ Email: dpurwana@unj.ac.id
}

\begin{abstract}
The objective of this research was to examine and analyze the effect of coach leadership, teamwork, and achievement motivation on the performance of Depok city' athletes. It was a quantitative research with associative approach, conducted at Depok National Sports Committee (KONI). The data were collected through questionnaire involving 203 samples of respondent of athletes and coach among Depok National Sports Committee. Data collection techniques carried out in this study were using questionnaire instruments. The items were derived from such variables (coaching leadership, teamwork, achievement motivation, and athlete's performance) using a likert scale which is used to allow the individuals to choose an answer in order to expressing how much they agree or disagree in such statement.

The data analysis and interpretation indicates that: (1) Coach' leadership has no direct effect on athletes' performance. (2) Coach' leadership has no direct effect on achievement motivation. (3) Coach' leadership has direct effect on teamwork. (4) Teamwork has direct effect on achievement motivation. (5) Teamwork has direct effect on athletes' performance. (6) Achievement motivation has direct effect on athletes' performance. (7) Coach' leadership has no indirect effect on athletes' performance through achievement motivation. (8) Coach' leadership has an indirect effect on athletes' performance through teamwork. (9) Coach' leadership has an indirect effect on athletes' performance through teamwork and achievement motivation. The implications in this study have the potential to contribute to a deeper understanding of things that can affect athlete performance; which consists of theoretical implications, research implications, policy implications, and practical implications. From several previous journals, research on the object under study, namely athletes is still relatively small. Even if there is, it only examines athletes in one sport. While in this study the object of his research was in many sports.
\end{abstract}

Keywords: Coach leadership, teamwork, achievement motivation, athlete's performance

\section{INTRODUCTION}

The Indonesian National Sports Committee (KONI) of Depok is a government partner organization formed in order to carry out the mandate of the National Sports System Law No.3 of 2006, where KONI is the only national sports organization authorized and responsible for managing, fostering, developing and coordinate every and all implementation of achievement sports activities for each member in the jurisdiction of the Unitary State of the Republic of Indonesia. KONI is a non-profit, independent non-governmental organization, and is not affiliated with any political power. West Java Regional Sports Event (PORDA) is a sports event attended by all cities / regencies in West Java, held every four years with the aim of finding outstanding athletes in West Java who can be trained and prepared for national and international sports week titles . To support this goal, the KONI Depok city in the period 
2012-2016 in the PORDA XII event in Bekasi, facilitated 24 sports, 110 athletes and 24 athletes coaches by providing stimulant funding for organizing and participating in events. However, the result of the medal of the KONI athletes in Depok city is still far from the planned target. Of the 12 sports facilitated by the Depok city KONI, only two achieved the targets of athletics and karate, seven sports did not reach the target, and three sports did not qualify for PORDA.

Performance is a measure of success in carrying out a job. (Robbins, 2017). Performance in the context of management is expressed as a process of communication carried out continuously in the framework of cooperation between an employee and his immediate supervisor (Bacal, 2014). In the case of athletes, the athlete's performance is the work that has been achieved in the activities following the training process in order to contribute to achieving the goals of the sports organization, namely achievement. McClelland argues that humans in interacting with their environment are often influenced by various motives. The motive is related to his existence as a biological being and social being that is always related to his environment. One of the motives put forward by McClelland is motivation for achievement.

Marks et al (2016: 357) explain that what is meant by team work is what the team does physically or mentally to achieve team goals, while teamwork is how the team does it. In terms of this research, teamwork is the collaboration of coaches of athletes and athletes and between athletes and other athletes. In this study, coach leadership is the process (activity) of a person by using charisma, intelligence, wisdom, and political skills and the ability of his art through the communication process to open up the potential competency of a person or group organized, guided, disciplined and empowered that potential towards greater competence in its efforts to set and achieve certain goals.

Previous studies of Zardoshtian et al (2014), Narwal (2014), Alfermann et al (2015), Rajabi (2012), and Weathington et al (2015) prove empirically that there is an influence of coach leadership on athlete performance. Previous studies of Barić and Bucik (2016), Soleimani et al (2014), HomayoniIzad et al (2016), Olympiou et al (2018), and Soyer et al (2014) proved empirically that there was influence of coach leadership on achievement motivation. Previous research by Chao (2016), Duygulu and Çıraklar (2016), Cormier et al (2015), and Aldoshan (2016) proved empirically that there was an influence of coach leadership on achievement motivation. c. Previous research by Irfan and Lodhi (2015) proved empirically that there was an effect of teamwork on achievement motivation. Previous research on Agwu (2015). Khan and Mashikhi (2017), Manzoor et al (2017), Ahmad and Manzoor (2017), McEwan et al (2017), and McEwan and Beauchamp (2014) empirically prove that there is an influence of teamwork on athlete performance. Previous research Bhatti and Haider (2014), Ngima and Kyongo (2013), Mili (2016), Adeyeye et al (2013), and Zuber and Conzelmann (2013) proved empirically that there was an effect of achievement motivation on athlete performance.

The purpose of this study is to find out and obtain a clear picture of whether or not there are: (1) Direct influence of coach leadership on athlete performance. (2) The direct influence of coach leadership on achievement motivation. (3) Direct influence of coach leadership on teamwork. (4) Direct influence of team collaboration on achievement motivation. (5) Direct influence of teamwork on athlete performance. (6) Direct influence of achievement motivation on athlete performance.

\section{LITERATURE REVIEW}

Performance is a measure of success in carrying out a job. (Robbins, 2017). Performance in the context of management is expressed as a process of communication carried out continuously in the framework of cooperation between an employee and his immediate supervisor (Bacal, 2014). In terms of personality, a person's performance in an organization is related to the personality of that person (Robbins, 2017). Judging from Vroom's motivational theory, it can be said that individuals will be motivated to do their best if he believes that his efforts will result in good performance appraisal, namely: good performance appraisal will receive rewards in the form of bonuses, salary increases, 
promotions so that the service is rewarded will satisfy or fulfill his personal goals: (Robbins, 2001). While Kreitner and Kinicki in Northouse (2013) state that leaders encourage higher performance by providing activities that influence subordinates to believe that valuable results can be achieved with serious effort. In the case of athletes, the athlete's performance is the work that has been achieved in the activities following the training process in order to contribute to achieving the goals of the sports organization, namely achievement.

Organizational behavior is a field of study devoted to understanding and explaining the attitudes and behavior of individuals and groups of individuals in the organization. In short, focus on why individuals and groups of individuals in an organization act like that. The final result of the study of organizational behavior is organizational performance and commitment, which is influenced by various factors including individual mechanisms, individual characteristics, group mechanisms, and organizational mechanisms. (Colquitt et al, 2015: 8) Individual mechanisms include job satisfaction; stress; motivation; trust, justice and ethics; learning and decision making. Individual characteristics include ability; and personality and cultural values. The group mechanism includes leadership style and behavior; power and leadership negotiations; team process and communication; team characteristics and variety. Organizational mechanisms include organizational culture and organizational structure. In this study performance was influenced by motivation, leadership, and teamwork.

McClelland argues that humans in interacting with their environment are often influenced by various motives. The motive is related to his existence as a biological being and social being that is always related to his environment. One of the motives put forward by McClelland is motivation for achievement. (Djiwandono, 2012) Motivation for achievement is a motive that encourages a person to achieve success in competing with a standard of excellence, both from the standard of achievement (autonomous standards) in the past or other people's achievements (social comparison standard).

Marks et al (2016: 357) explain that what is meant by team work is what the team does physically or mentally to achieve team goals, while teamwork is how the team does it. team collaboration is a group of individuals who are interdependent in completing tasks, have the same goals and responsibilities, interact and connect with other groups in an organization. In terms of this research, teamwork is the collaboration of coaches of athletes and athletes and between athletes and other athletes.

According to Sukadiyanto (2012: 4) "The trainer is a person who has professional abilities to help reveal the potential of sportsmen to be optimally tangible abilities in a relatively short time" The trainer is one of the human resources in sports that plays a very important role in the achievement of the athletes who are trained (Budiwanto 2014: 6). The trainer is the key that must understand the correct training procedures, namely by mastering the training knowledge or training theory and methodology that can be used as a basis for conducting training activities (Irianto, 2012). In this study, coach leadership is the process (activity) of a person by using charisma, intelligence, wisdom, and political skills and the ability of his art through the communication process to open up the potential competency of a person or group organized, guided, disciplined and empowered that potential towards greater competence in its efforts to set and achieve certain goals.

\section{METHODOLOGY}

The study was conducted in the KONI city of Depok, involving 203 samples of athletes, coaches and sports coordinators. The total sample size of 203 respondents was represented proportionally by 33 sports, 134 male athletes, 69 female athletes. Thus it can be concluded that the characteristics of the research respondents have been attempted to represent the characteristics of the population proportionally. This study uses a quantitative approach, a survey method with causal analysis, which can be described as follows: 


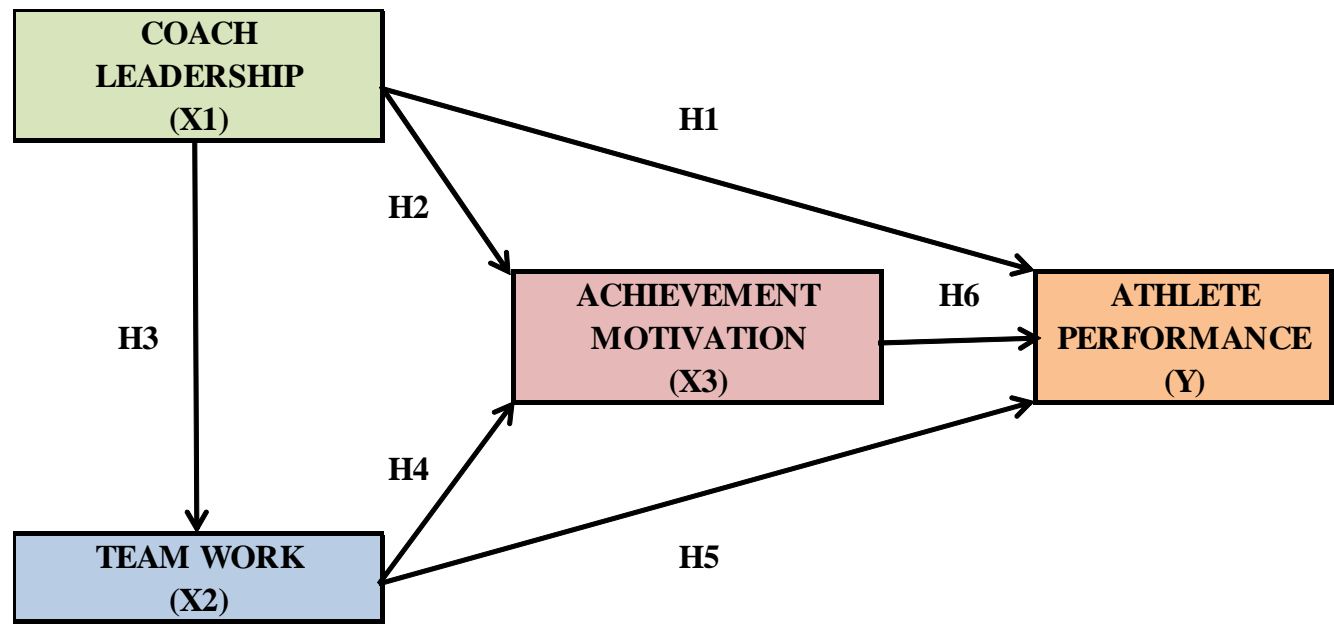

Figure 1. Research Hypothetic Model

The indicators of each variable are as follows:

\begin{tabular}{|c|c|c|c|}
\hline Variable & Dimension & Indicator & Reference \\
\hline \multirow{6}{*}{$\begin{array}{l}\text { Coach } \\
\text { Leadership (X1) }\end{array}$} & \multirow{3}{*}{ People centered } & $\begin{array}{l}\text { Emphasizes the importance of } \\
\text { meeting the needs of athletes }\end{array}$ & \multirow{6}{*}{$\begin{array}{l}\text { Northouse, 2013; } \\
\text { Stogdill, 2014; } \\
\text { Carlyle, 2015 }\end{array}$} \\
\hline & & $\begin{array}{l}\text { prioritizing good interactions with } \\
\text { athletes and people around }\end{array}$ & \\
\hline & & Motivating athlete's fighting spirit & \\
\hline & \multirow{3}{*}{ Task oriented } & Focus on achieving victory & \\
\hline & & $\begin{array}{l}\text { Generally successful in carrying out } \\
\text { tasks }\end{array}$ & \\
\hline & & $\begin{array}{l}\text { Maintain harmonious relationships } \\
\text { with team members }\end{array}$ & \\
\hline \multirow{6}{*}{$\begin{array}{l}\text { Team } \\
\text { Cooperation } \\
\text { (X2) }\end{array}$} & \multirow[t]{6}{*}{ Team's success } & $\begin{array}{l}\text { Commitment to team success and } \\
\text { shared goals }\end{array}$ & \multirow{6}{*}{$\begin{array}{l}\text { Johnson, 2017; Beal, } \\
\text { 2013; Delarue and } \\
\text { Prins, 2014; O'leary } \\
\text { et. al, 2014 }\end{array}$} \\
\hline & & Positive interdependence & \\
\hline & & Team management skills & \\
\hline & & $\begin{array}{l}\text { Open communication and positive } \\
\text { feedback }\end{array}$ & \\
\hline & & Adequate team composition & \\
\hline & & $\begin{array}{l}\text { Commitment to team processes, } \\
\text { leadership and accountability. }\end{array}$ & \\
\hline \multirow{11}{*}{$\begin{array}{l}\text { Achievement } \\
\text { Motivation (X3) }\end{array}$} & \multirow[t]{4}{*}{ Intrinsic factor } & Possibility of success & \multirow{11}{*}{$\begin{array}{l}\text { McCelland, 2018; } \\
\text { Zanobini and Usui, } \\
\text { 2014; Bernstein and } \\
\text { Maier, } 2015\end{array}$} \\
\hline & & Self-efficacy & \\
\hline & & Value & \\
\hline & & Fear of failure & \\
\hline & \multirow{7}{*}{$\begin{array}{l}\text { Extrinsic } \\
\text { factor }\end{array}$} & Relationship coach with athletes & \\
\hline & & Relationship between fellow athletes & \\
\hline & & Coaching and training system & \\
\hline & & Welfare system & \\
\hline & & $\begin{array}{l}\text { Physical environment where to } \\
\text { practice }\end{array}$ & \\
\hline & & Athlete status & \\
\hline & & $\begin{array}{l}\text { Administration and policy of KONI } \\
\text { Depok }\end{array}$ & \\
\hline \multirow{7}{*}{$\begin{array}{l}\text { Athlete } \\
\text { Performance (Y) }\end{array}$} & \multirow[t]{7}{*}{ Personality } & Prestigious ambition & \multirow{7}{*}{$\begin{array}{l}\text { Brown, 2015; } \\
\text { Greenleaf, Gould \& } \\
\text { Dieffenbach, 2015; } \\
\text { Orlick, } 2016\end{array}$} \\
\hline & & Hard work & \\
\hline & & Persistent & \\
\hline & & Commitment & \\
\hline & & Mandiri & \\
\hline & & Intelligent & \\
\hline & & Self-control & \\
\hline
\end{tabular}


Data collection techniques carried out in this study were using questionnaire instruments. The questionnaire used consisted of questionnaires, variables of coach leadership, teamwork, achievement motivation and athlete's performance. The type of questionnaire is a closed questionnaire where the questionnaire distributed to respondents has provided the answer in the form of five answer choices, so the respondent just has to choose one of the five answers provided. The measurement scale of the coach leadership questionnaire, teamwork, achievement motivation and athlete's performance used a Likert scale with the following alternative answers: "strongly agree" was given a score of 5; "Agree" is given a score of 4; "Disagree" is given a score of 3; "Disagree" is given a score of 2; and "strongly disagree" was given a score of 1 . Primary data collected later through the estimated error normality test, linearity test and significance test. Then analyzed and tested the hypothesis using path analysis. Data analysis techniques in this study include: (1) descriptive data analysis, (2) requirements test, (3) inferential data analysis.

\section{RESULT AND DISCUSSION}

The data description is the questionnaire answer score variable athletes performance (Y), coach leadership (X1), teamwork (X2), and achievement motivation (X3). The results of data collection will be processed using descriptive statistical techniques which consist of calculating the average value, standard deviation, median variance, mode, minimum value, maximum value, range and frequency distribution accompanied by histograms.

Table 1. Frequency Distribution of Athlete Performance Scores (Y)

\begin{tabular}{|c|c|c|c|c|}
\hline CLASS & $\mathbf{F}$ & $\% F$ & F KUM & \%F KUM \\
\hline $47.5-60.5$ & 28 & 13.79 & 28 & 13.79 \\
\hline $60.5-73.5$ & 21 & 10.34 & 49 & 24.14 \\
\hline $73.5-86.5$ & 23 & 11.33 & 72 & 35.47 \\
\hline $86.5-99.5$ & 24 & 11.82 & 96 & 47.29 \\
\hline $99.5-112.5$ & 28 & 13.79 & 124 & 61.08 \\
\hline $112.5-125.5$ & 21 & 10.34 & 145 & 71.43 \\
\hline $125.5-138.5$ & 19 & 9.36 & 164 & 80.79 \\
\hline $138.5-151.5$ & 12 & 5.91 & 176 & 86.70 \\
\hline $151.5-165$ & 27 & 13.30 & 203 & 100.00 \\
\hline
\end{tabular}

Figure 2. Histogram of Data Frequency Athletes Performance Variables (Y)




Table 2. Distribution of Frequency of Coach Leadership Scores (X1)

\begin{tabular}{ccccc}
\hline CLASS & F & \%F & F KUM & \%F KUM \\
\hline $47.5-55.5$ & 18 & 8.87 & 18 & 8.87 \\
$55.5-63.5$ & 20 & 9.85 & 38 & 18.72 \\
$63.5-71.5$ & 20 & 9.85 & 58 & 28.57 \\
$71.5-79.5$ & 30 & 14.78 & 88 & 43.35 \\
$79.5-87.5$ & 31 & 15.27 & 119 & 58.62 \\
$87.5-95.5$ & 29 & 14.29 & 148 & 72.91 \\
$95.5-103.5$ & 21 & 10.34 & 169 & 83.25 \\
$103.5-111.5$ & 18 & 8.87 & 187 & 92.12 \\
$111.5-120$ & 16 & 7.88 & 203 & 100.00 \\
\hline \multicolumn{7}{c}{203} & 100.00 & &
\end{tabular}

Figure 3. Histogram of Data Frequency Coach Leadership Variables (X1)

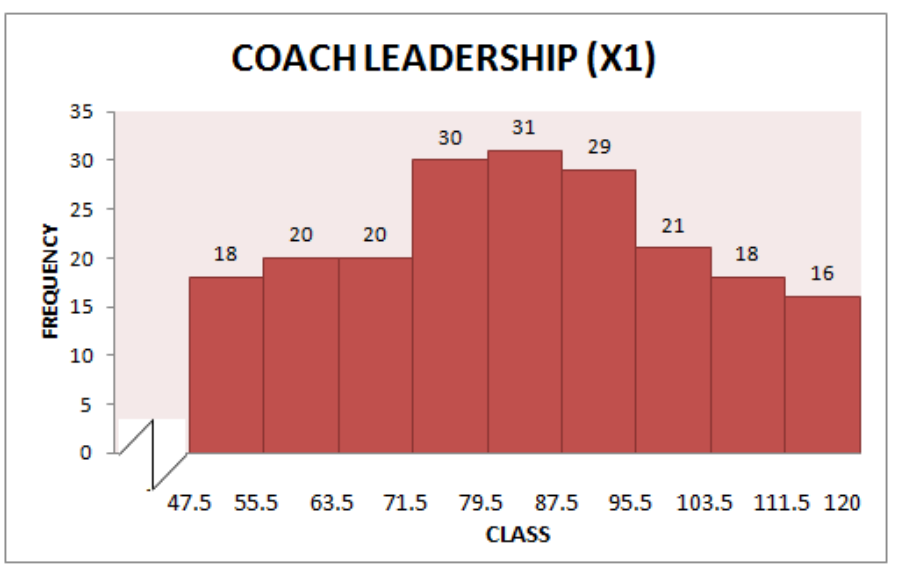

Table 3. Distribution of Frequency of Team Cooperation Scores (X2)

\begin{tabular}{|c|c|c|c|c|}
\hline CLASS & $\mathbf{F}$ & $\% F$ & F KUM & \%F KUM \\
\hline $57.5-67.5$ & 17 & 8.37 & 17 & 8.37 \\
\hline $67.5-77.5$ & 23 & 11.33 & 40 & 19.70 \\
\hline $77.5-87.5$ & 24 & 11.82 & 64 & 31.53 \\
\hline 87.5 - 97.5 & 29 & 14.29 & 93 & 45.81 \\
\hline $97.5-107.5$ & 35 & 17.24 & 128 & 63.05 \\
\hline $107.5-117.5$ & 27 & 13.30 & 155 & 76.35 \\
\hline 117.5 - 127.5 & 18 & 8.87 & 173 & 85.22 \\
\hline 127.5 - 137.5 & 21 & 10.34 & 194 & 95.57 \\
\hline \multirow[t]{2}{*}{$137.5-147.5$} & 9 & 4.43 & 203 & 100.00 \\
\hline & 203 & 100.0 & & \\
\hline
\end{tabular}

Figure 4. Histogram of Data Frequency Variable Teamwork (X2)

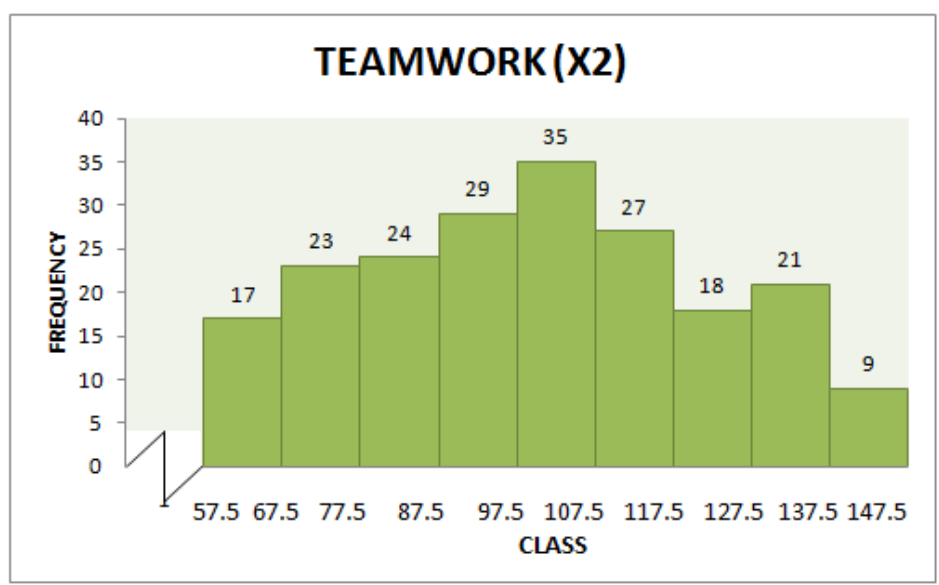


Table 4. Frequency Distribution of Achievement Motivation Score (X3)

\begin{tabular}{|c|c|c|c|c|}
\hline CLASS & $\mathbf{F}$ & $\% F$ & F KUM & \%F KUM \\
\hline $65.5-76.5$ & 24 & 11.82 & 24 & 11.82 \\
\hline 76.5 - 87.5 & 18 & 8.87 & 42 & 20.69 \\
\hline $87.5-98.5$ & 21 & 10.34 & 63 & 31.03 \\
\hline $98.5-109.5$ & 24 & 11.82 & 87 & 42.86 \\
\hline $109.5-120.5$ & 27 & 13.30 & 114 & 56.16 \\
\hline $120.5-131.5$ & 24 & 11.82 & 138 & 67.98 \\
\hline $131.5-142.5$ & 18 & 8.87 & 156 & 76.85 \\
\hline $142.5-153.5$ & 20 & 9.85 & 176 & 86.70 \\
\hline $153.5-165$ & 27 & 13.30 & 203 & 100.00 \\
\hline
\end{tabular}

Figure 5. Histogram of Data Frequency Variable Achievement Motivation (X3)

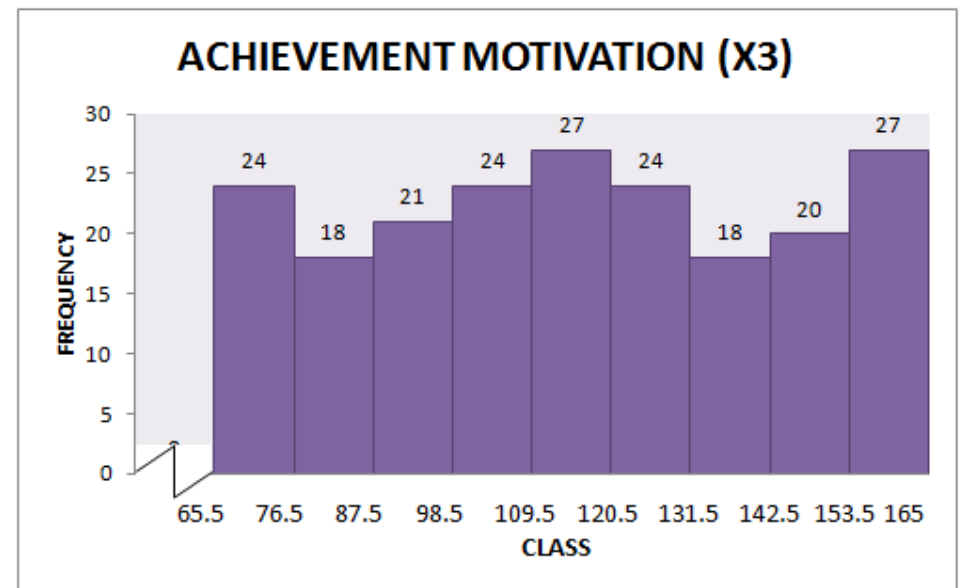

Table 5. Summary of Descriptions of Research Data Statistics

\begin{tabular}{|c|c|c|c|c|c|}
\hline \multicolumn{6}{|c|}{ Statistics } \\
\hline & & $C L$ & TW & AM & AP \\
\hline \multirow[t]{2}{*}{$\bar{N}$} & Valid & 203 & 203 & 203 & 203 \\
\hline & Missing & 0 & 0 & 0 & 0 \\
\hline \multicolumn{2}{|c|}{ Mean } & 82.75 & 100.01 & 115.68 & 103.09 \\
\hline \multicolumn{2}{|c|}{ Median } & 82.00 & 100.00 & 118.00 & 102.00 \\
\hline \multicolumn{2}{|c|}{ Mode } & 80 & 87 & $69^{a}$ & 107 \\
\hline \multicolumn{2}{|c|}{ Std. Deviation } & 18.821 & 22.745 & 28.600 & 34.463 \\
\hline \multicolumn{2}{|c|}{ Variance } & 354.239 & 517.327 & 817.961 & 1187.725 \\
\hline \multicolumn{2}{|c|}{ Range } & 72 & 86 & 99 & 117 \\
\hline \multicolumn{2}{|c|}{ Minimum } & 48 & 58 & 66 & 48 \\
\hline \multicolumn{2}{|c|}{ Maximum } & 120 & 144 & 165 & 165 \\
\hline \multicolumn{2}{|c|}{ Sum } & 16798 & 20302 & 23483 & 20927 \\
\hline
\end{tabular}

In this study, the analysis requirements testing used was the normality test, homogeneity test and significance test. The description of the results of testing the requirements of the analysis are as follows: Normality testing is done statistically using the Liliefors formula, with the following results: 
Table 6. Summary of Normality Test Results

\begin{tabular}{ccccc}
\hline VARIABLE & N & L-count & L-table & CONCLUSION \\
\hline X2 on X1 & 203 & 0.042309 & 0.062325 & Normal \\
X3 on X1 & 203 & 0.033635 & 0.062325 & Normal \\
X3 on X2 & 203 & 0.040198 & 0.062325 & Normal \\
Y on X1 & 203 & 0.058135 & 0.062325 & Normal \\
Y on X2 & 203 & 0.056437 & 0.062325 & Normal \\
Y on X3 & 203 & 0.031865 & 0.062325 & Normal \\
\hline
\end{tabular}

Linearity testing uses ANOVA (Analysis of Variance) and significance test with F test; with the following results:

Table 7. Summary of Regression Linearity Test

\begin{tabular}{ccccc}
\hline & & \multicolumn{2}{c}{ F-value } & \\
Variable & Regression Equation & Deviation from linierity & Conclusion \\
\cline { 3 - 4 } & & F-count & F-table & \\
\hline Y onX1 & $\mathrm{Y}=-47.858+1.824 \mathrm{X} 1$ & 20.69638 & 1.402516 & Linier \\
Y on X2 & $\mathrm{Y}=-48.080+1.512 \mathrm{X} 2$ & 13.58237 & 1.392397 & Linier \\
Y on X3 & $\mathrm{Y}=-36.045+1.203 \mathrm{X} 3$ & 11.72119 & 1.388573 & Linier \\
$\mathrm{X} 2$ on X1 & $\mathrm{X} 2=0.18276+1.206 \mathrm{X} 1$ & 5.781471 & 1.402516 & Linier \\
$\mathrm{X} 3$ on X1 & $\mathrm{X} 3=-9.5331+1.513 \mathrm{X} 1$ & 23.62238 & 1.402516 & Linier \\
$\mathrm{X} 3$ on X2 & $\mathrm{X} 3=-9.6853+1.254 \mathrm{X} 2$ & 12.47582 & 1.392397 & Linier \\
\hline
\end{tabular}

The results of the calculation of the path coefficient by manual and using SPSS version 17 software, produce the following results:

Table 8. Summary of Path Coefficient Calculations

\begin{tabular}{clcc}
\hline \multirow{2}{*}{ Substructure } & \multicolumn{1}{c}{ Effect } & \multicolumn{2}{c}{ Path Coefficient } \\
\cline { 3 - 4 } & & Manual & SPSS \\
\hline \multirow{2}{*}{1} & Coach Leadership on Athlete Performance & -0.001 & -0.001 \\
& Teamwork on Athlete Performance & 0.412 & 0.412 \\
& Achievement Motivation on Athlete Performance & 0.588 & 0.588 \\
\hline \multirow{2}{*}{2} & Coach Leadership on Achjevement Motivation & 0.178 & 0.178 \\
& Teamwork on Achievement Motivation & 0.819 & 0.819 \\
\hline 3 & Coach Leadership on Teamwork & 0.998 & 0.998 \\
\hline
\end{tabular}

Table 9. Summary of Hypothesis Testing Results

\begin{tabular}{lllll}
\hline Analysis & $\begin{array}{l}\text { Path } \\
\text { Coefficient }\end{array}$ & t-count & t-table & Test Conclusion \\
\hline X1 on Y & -0.001 & -0.017 & 1.972 & X1 has no direct effect on Y \\
\hline X1 on X3 & 0.178 & 1.891 & 1.972 & X1 has no direct effect on X3 \\
\hline X1 on X2 & 0.998 & 58381 & 1.972 & X1 has direct effect on X2 \\
\hline X2 on X3 & 0.819 & 8.705 & 1.972 & X2 has direct effect on X3 \\
\hline X2 on Y & 0.412 & 5.580 & 1.972 & X2 has direct effect on Y \\
\hline X3 on Y & 0.588 & 12.444 & 1.972 & X3 has direct effect on Y \\
\hline
\end{tabular}


Thus the final model of path analysis can be seen in the following figure below:

Figure 6. Final Path Analysis Model

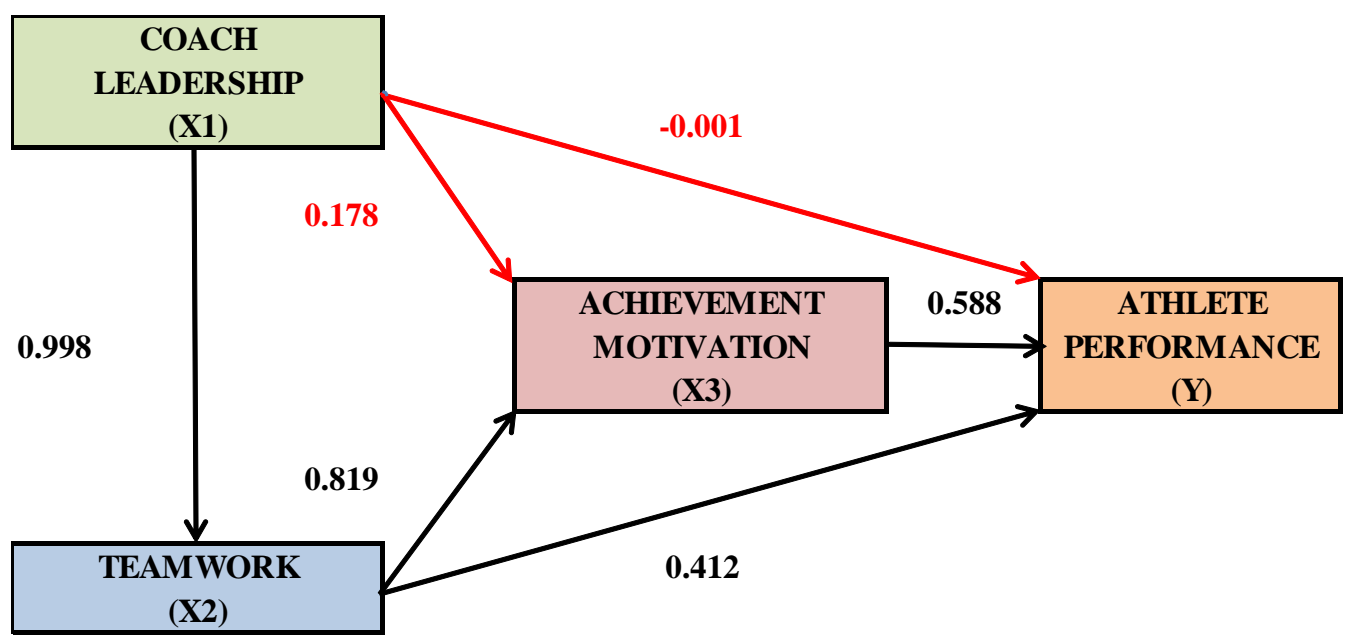

Based on the description of the results of the analysis and testing of the hypothesis it can be identified that of the six hypotheses put forward in the study it was proven four direct influences and two no effect. In detail, the discussion of the analysis and testing of the research hypothesis can be described as follows. Effect of coach leadership on athlete performance. Research conducted on athletes in the KONI neighborhood of Depok city turned out to show that the leadership of the coach did not directly influence the performance of athletes. So this condition is contrary to the expressions of previous researchers and the opinion of Gary Collins in Stoltzfus (2005) which states that training is the art and practice of guiding a person or group of people from their initial existence to greater competence and fulfilling their desires.

The empirical results of the absence of direct influence of coach leadership on the performance of the KONI athletes in Depok made an explanation why the PORDA title in the KONI city of Depok could not reach the planned gold medal target (from 12 sports facilitated by KONI Depok city, only 2 reached the target) namely athletics and karate, 7 sports did not reach the target, and 3 sports did not qualify for PORDA). The results of research that show no influence of coach leadership on athlete performance are indications that there are problems in the leadership aspects of the trainers, or the competency aspects of the trainers, or a combination of the two aspects. The indication of the coach leadership's problems is an input for the KONI in the city of Depok so that in the future it can improve and give more attention to efforts to improve the leadership of the coach in order to improve the performance of athletes.

Effect of coach leadership on athlete achievement motivation. In this study it was found that the leadership of the coach did not or did not influence the formation or increase of achievement motivation of athletes. So that this condition is contrary to the expressions of previous researchers and the opinion of Stoltzfus (2005) which states that training is to practice the discipline of trusting the community in order to empower them to change. The empirical results are not significant, the direct influence of coach leadership on achievement motivation of KONI athletes in Depok city again makes the explanation why in the 2017 PORDA title KONI Depok city cannot reach the planned gold medal target. There is no or less significant influence of coach leadership on achievement motivation of KONI athletes in the city of Depok indicating that there are problems with the relationship of coaches and athletes or problems with the system of coaching and training, or a combination of these two motivational aspects of motivation. This indication of the coach leadership's problems is an input for the KONI in the city of Depok so that in the future it can improve and give more attention to efforts to improve the coach's leadership in order to increase athletes' achievement motivation.

Effect of coach leadership on teamwork. In this study, it was found that the leadership of the coach had a direct effect on teamwork. The results of this study are in line with 
previous studies and in line with the opinion of Northouse (2013) which states that leadership is a process where individuals influence a group of individuals to achieve a common goal. The results of this study also prove that trainers in the KONI city of Depok are open in communication and can receive positive feedback from all parties, and have formed an adequate team composition that can satisfy all parties.

Effect of teamwork on athlete achievement motivation. In the study of athletes in the KONI neighborhood of Depok, it was found that teamwork had a significant direct effect on the athletes' achievement motivation. The results of this study are in line with the previous research mentioned above and in line with the opinion of McClelland (1985) which states that achievement motivation is influenced by two factors, namely intrinsic factors and extrinsic factors. Extrinsic factors that affect achievement motivation include the relationship of the coach and athlete, and the relationship between fellow athletes; or in other words how teamwork is built. The results of this study indicate that the collaboration of teams built in the Depok city KONI between athletes and other athletes and between athletes and coaches has been able to increase the achievement motivation of athletes individually and as a team, which in turn will improve athletes' performance.

Effect of teamwork on the performance of athletes. In the study of athletes in the KONI neighborhood of Depok, it was found that team collaboration had a significant direct effect on athletes' performance. The results of this study are in line with the previous research mentioned above and in line with the opinion of Luca and Tarricone (2001) which states that the success of team collaboration depends on the existence of synergy between team members creating an environment where they want to contribute and participate to promote and maintain a positive team environment and effective. The results of this study indicate that the collaboration of teams built in the Depok city KONI between athletes and other athletes and between athletes and their coaches has been able to improve the performance of athletes individually and as a team.

Effect of athlete achievement motivation on athlete performance. In the study of athletes in the KONI neighborhood of Depok, it was found that achievement motivation had a significant direct effect on athlete performance. The results of this study are in line with the previous research mentioned above and in line with expectancy theory developed by Vroom (Robbins, 2001) which states that individuals will be motivated to try as much as possible if he believes that his efforts will produce good performance evaluations, namely: good performance will receive rewards in the form of bonuses, salary increases, promotions so that these services will satisfy or fulfill their personal goals. The results of this study indicate that achievement motivation of athletes in the KONI environment in Depok city is believed to be able to improve the performance of athletes individually and as a team.

\section{CONCLUSION}

Based on the results of the analysis and discussion of the results of the research analysis; can be identified research findings with conclusions as follows: 1. Coach leadership does not directly influence the athlete's performance. 2. Coach leadership does not directly influence athlete achievement motivation.3. Coach leadership has a direct effect on teamwork. 4. Team collaboration has a direct effect on achievement motivation.5. Team collaboration has a direct effect on the performance of athletes.6. Motivation for achievement directly influences the performance of athletes.

The findings of this study are expected to provide the following benefits: 1 . The results of this study are expected to provide benefits to the development of science in the field of human resource management in general and the performance of sports organizations in particular. 2. The results of this study are expected to enrich the references and literature in the world of literature about the application of human resource management studies in sports organizations. 3. The results of this study can be used as a reference for writing and similar research for the next stage. 


\section{REFERENCES}

Adeyeye, F.M., J. B. Vipene, dan D. A. Asak. 2013. "The Impact of Motivation on Athletic Achievement: a Case Study of The 18th National Sports Festival, Lagos, Nigeria". Academic Research International Vol. 4 No. 5 September 2013: 378- 383

Agwu, Mba Okechukwu. "Teamwork and Employee Performance in The bonny Nigeria Liquefied Natural Gas Plant", Strategic Management Quarterly, Vol. 3(4), December 2015, hh 39-60

Ahmad, Iftikhar dan Sheikh Raheel Manzoor, "Effect of Teamwork, Employee Empowerment and Training on Employee Performance", International Journal of Academic Research in Business and Social Sciences, Vol. 7, No. 11, 2017, hh 380394

Aldoshan, Khater. 2016. "Leadership Styles Promote Teamwork." International Journal of Scientific \& Technology Research Volume 5, Issue 06, June 2016, hh 1-4

Alfermann, Dorothee., Martin J. Lee, dan Sabine Würth. 2015. "Perceived Leadership Behavior and Motivational Climate as Antecedents of Adolescent Athletes' Skill Development.” The Online Journal of Sport Psychology July, 2015 Volume 7, Issue 2, 14-36

Bacal, Robert. How to Manage Performance, Dialihbahasakan oleh Jully, Jakarta: Gramedia, 2014

Barić, Renata and Valentin Bucik. 2016. "Motivational Differences in Athletes Trained by Coaches of Different Motivational and Leadership Profiles." Kinesiology 41(2016) 2:181-194

Bhatti, Saleem Raza dan Sheema Haider. "The Impact of Employees' Motivation on Performance: Findings from Karachi Based Service Organization”. IJMS, Volume 2, Issue 1, 2014, hh 11-20

Budiwanto, S. 2014. Pengetahuan Dasar Melatih Olahraga. Malang: Depdiknas Universitas Negeri Malang.

Chao, Chien Chen. 2016. "Leadership and teamwork paradigms: Two models for baseball coaches." Social Behavior and Personality, 2016, 38(10), 1367-1376

Colquitt, Jason A.; Jeffery A. LePine; dan Michael J. Wesson. Organizational Behavior Improving Performance and Commitment in the Workplace. New York: The McGraw-Hill Companies, Inc., 2015

Cormier, Marc L., Gordon A. Bloom dan William J. Harvey. 2015. "Elite Coach Perceptions of Cohesion on Coacting Teams." International Journal of Sports Science \& Coaching Volume 10 - Number 6 - 2015: hh 1039-1053

Duygulu, Ethem dan Nurcan Çıraklar. 2016. "Effects of Leadership Roles on Team Effectiveness." Ege Academic Review 9 (2) 2016: 389-400

Homayoni Izad, Negar., Rokhsareh Badami, Bahman Baluch, dan Linda J. Duffy. 2016. "The Perception of Same Gender Coaches by Iranian Skaters and its Influence on Sport Achievement Motivation and Commitment." International Journal of Science Culture and Sport March 2016 4(1) hh 1-13

Irfan, Misbah dan Samreen Lodhi. "Impact of Teamwork on Employee Motivation: A Case of Banking Sector of Pakistan" The International Journal Of Business \& Management Vol 3 Issue 11, November, 2015, hh 26- 33

Irianto, Djoko Pekik. 2012. Dasar dasar Kepelatihan. Yogyakarta: FIK UNY

Khan, Sheeba dan Layal Said Al Mashikhi, "Impact of Teamwork on Employees Performance", International Journal of Education and Social Science, Vol. 4 No. 11; December 2017, hh 14-22

Manzoor, Sheikh Raheel., HafizUllah, Murad Hussain, dan Zulqarnain Muhammad Ahmad. "Effect of Teamwork on Employee Performance", International Journal of Learning \& Development, Vol. 1, No. 1, 2017, hh 110-126

Marks, M. A., J. E. Mathieu, dan S. J. Zaccaro, "A Temporally Based Framework and Taxonomy of Team Processes". Academy of Management Review, 26(3), 2016, hh 356-376. 
McClelland, D.C. Methods of Measuring Human Motivation. In: J. W. Atkinson, ed., Motives in Fantasy, Action and Society. Princeton, N.J.: Van Nos-trand. 2018

McClelland, D. Human Motivation. Glenview: Scott Foreman, 2015

McEwan, Desmond., Geralyn R. Ruissen, Mark A. Eys, Bruno D. Zumbo, dan Mark R. Beauchamp. 2017. "The Effectiveness of Teamwork Training on Teamwork Behaviors and Team Performance: A Systematic Review and Meta-Analysis of Controlled Interventions." PLOS ONE journal.pone.0169604 January 13, 2017, hh 123

McEwan, Desmond dan Mark R. Beauchamp. 2014. "Teamwork in sport: a theoretical and integrative review." International Review of Sport and Exercise Psychology 2014 Vol. 7, No. 1, 229-250

Mili, Anil. 2016. "A comparison of sports achievement motivation between the medal winning and non-medal winning athletes in the inter college sports tournaments." International Journal of Physical Education, Sports and Health 2016; 3(6): 72-73

Narwal, Rekha. 2014. "Effect of Coaching Behavior in Sports." International Journal of Enhanced Research in Educational Development (IJERED), Vol. 2, Issue 4, JulyAugust, 2014, pp: (111-115)

Ngima, Wanjau Mary dan Joanes Kyongo. "Contribution of Motivational Management to Employee Performance", International Journal of Humanities and Social Science, Vol. 3 No. 14, July 2013, hh 219-239

Northouse, Peter G. 2013. Kepemimpinan : Teori dan Praktik. Jakata : PT Indeks

Olympiou, Alkisti., Sophia Jowett, dan Joan L. Duda. 2018. "The Psychological Interface Between the Coach-Created Motivational Climate and the Coach-Athlete Relationship in Team Sports." The Sport Psychologist, 2018, 22, 423-438

Rajabi, Zahra. 2012. "Relationship of coach's leadership style and player performance outcomes." European Journal of Experimental Biology, 2012, 2 (4):1134-1136

Robbins, Stephen P. Essential of Organizational Behavior. New Jersey: Prentice Hall, 2017

Robbins, Stephen P. Organizational Behavior. New Jersey: Prentice Hall, 2011

Soleimani, Majid., Sirus Ahmadi, and Hamideh Langari. 2014. "The relationship between, style leadership coaches and achievement motivation female athletes fitness field of Bojnoord city." Journal of Novel Applied Sciences 2014-3-5/557-561

Soyer, Fikret., Ihsan Sari, dan Laurentiu-Gabriel Talaghir. 2014. "The relationship between perceived coaching behaviour and achievement motivation: a research in football players." Procedia - Social and Behavioral Sciences 152 ( 2014 ) 421 - 425

Stoltzfus, Tony. 2015. Leadership Coaching: The Disciplines, Skills and Heart of a Coach. Virginia Beach: ISBN 1-4196-1050-3

Sukadiyanto. 2012. Teori Dan Metodologi Melatih Fisik Petenis. Yogyakarta: FIK UNY

Weathington, Bart L., Amanda C. Alexander, and Laure L. Rodebaugh. 2015. "Coaching Influences on Student-Athlete Motivation, Stress, and Skill." Athletic Insight Journal Volume 2, Issue 2, pp. 1-18

Zardoshtian, Shirin., Rasool Norouzi Seyed Hossini, and Younis Mohammadzade. 2014. "The Relationship between leadership styles of coaches with self-determination and burn-out of the Iranian elite female Volleyball players." International Journal of Academic Research in Business and Social Sciences January 2014, Vol. 2, No. 1 hh 30-37

Zuber, Claudia dan Achim Conzelmann. 2013. "The impact of the achievement motive on athletic performance in adolescent football players." European Journal of Sport Science, University of Bern, Bern, Switzerland, 2013, hh 1-9 